\title{
研究 報告
}

\section{胸部大動脈瘤ステントグラフト内挿術を受けた 後期高齢者の治療体験と看護支援の検討}

\author{
Treatment Experience and Nursing Care of Elderly Adults Aged 75 and over \\ Who Underwent Thoracic Endovascular Aneurysm Repair
}

\begin{abstract}
冨田亜沙子 井上智子
Asako Tomita Tomoko Inoue

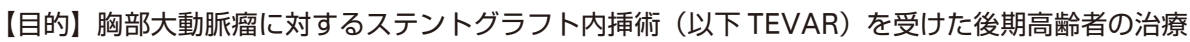
体験を通して療養生活を明らかにし, TEVAR を受ける高齢患者への看護支援の示唆を得る.

【方法】75 歳以上で調査期間中に外来受診し研究の参加に同意を得られた者に, 半構造的面接調查を 行い，得られたデータを修正版グラウンデットセオリーアプローチに基づき分析した.

【結果】対象は 13 名, 平均年齢 $78.3( \pm 3.9)$ 歳だった. 対象者は治療前に低侵襲治療に期待を持つ 一方で, 手術か天寿全うか葛藤を抱き, 治療後は体の負担の軽い手術と感じる者と楽ではないと感 じる者がみられた. 退院後は「治療と老いの双方の影響で生じた日常生活上の困難」がある一方で, 「治療と老いに対して抱いた前向きな価值観」を見出していた。

【結論】後期高粹患者が治療を受けるが故, 療養生活において治療の影響だけではなく老いに伴う变 化がみられた．そのため, 治療後も自立した日常生活が維持出来るような看護援助が重要である.
\end{abstract}

キーワード：胸部大動脈痹ステントグラフト内拪術，後期高齢者，低侵襲治療，治療体験

Key Words: TEVAR, elderly aged 75 and over, minimally invasive treatment, treatment experience

\section{I . はじめに}

本邦において，高齢化の進行と CT をはじめとした スクリーニング検査の普及から, 大動脈病変と診断さ れる患者が増加している1 ${ }^{1}$. 従来の人工血管置換術に 変わり，大動脈瘤の中枢側と末梢側の正常血管にステ ントグラフトを固定し，瘤への血流を遮断する血管内 アプローチが新たに登場した。 その中でも胸部大動 脈瘤（thoracic aortic aneurysm：以下 TAA）に対するス テントグラフト内挿術（thoracic endovascular aneurysm repair：以下 TEVAR）は, 治療件数が飛躍的に増加し ている ${ }^{1,2)}$. TEVAR は低侵襲治療であるため, 多く の場合, 術後翌日には食事開始並びに歩行可能とな

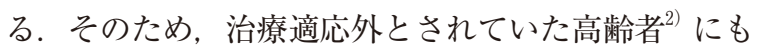
実施されるようになった，特に，75歳以上の場合に TEVAR を第 1 選択 ${ }^{3)}$ とすることが推奨されており, 患者の大半は後期高龄者という現状がある.

また，TAA に対し人工血管置換術を受けた患者を 対象とした研究では, 術後の生活に打いて以前の日常 からの乘離を実感し, 術後の合併症や様々な苦痛症 状，体力の低下などを自覚することで手術前の日常生 活との違いを痛感する ${ }^{4)}$ と報告されている，手術前後 に変化が生じ日常生活上の困難が存在することは他の 領域の手術に抏いても，明らかになっている，さら に, 冠動脈バイパス術を受けた患者は, 手術後, 疾患 と折り合いを付けながら如何に生活の再編を行ってい くかに関心が向けられる゙5) との報告がある。しかし， 
TEVARに着目をすると新しい治療であるが故, 人工 血管置換術との治療成績の比較やデバイスに関する報 告 ${ }^{1)}$ はあるが, 手術前後の日常生活の様子等を示した 文献は見当たらない. 高齢化社会の進行は, 止める ことは出来ず, 後期高齢者が治療を受ける機会は増 える、しかしながら新しく始まった治療方法である TEVARを受けた後期高齢者の思いや考元, 日常生活 の様子, さらに必要となる看護支援は明らかでない. そのため, 本研究では, TEVARを受けた後期高齢者 の治療体験を明らかにし, その結果から, TEVARを 受ける高齢患者への看護支援の在り方について示唆を 得ることとする.

\section{II. 用語の定義}

治療体験：胸部大動脈瘤の診断がなされ, TEVAR を受ける前から手術後, 退院後の日常生活を送る中で 感じた思いや考えた事, 療養生活の様子とする.

\section{III. 研究方法}

\section{1. 対象}

首都圈 $\mathrm{A}$ 大学病院において, 75 歳以上で TEVAR を受け, 外来受診期間が定期的に設けられている術後 3 か月以上 2 年以内の外来受診が可能で研究の参加に 同意を得られた者とした. なお, 精神疾患や認知機能 障害と診断された者は除外した。

\section{2. 調査期間}

平成 26 年 6 月 9 月

\section{3．調査方法および調査内容}

\section{1 ) 面接調查}

面接調查は, 外来受診時に, プライバシーの確保が 出来る個室で行い, 対象者の許可を得られた場合, IC レコーダーに録音した，面接後，逐語録を作成し， データとした．面接は，インタビューガイドを使用 し, 半構造的面接を 1 人につき 1 回行った.

内容は, TAAを診断された時期から実際に手術が 行われ, 現在までの治療過程で感じたことや抱いた思 い, 身体的な状況, 日常生活の様子などを, 手術前, 手術直後, 退院後と語りやすいように時期毎に, 振り 返りながら出来る限り自由に語ってもらった。

\section{2 ) 診療録調查}

対象者の診療録，看護記録より属性や既往歴，手術 記録，入院の様子，身体機能，手術の受け止め，退院 後の経過の情報を得た.

\section{3 ) 分析方法}

面接デー夕は時間的経過の中で変化するプロセス 的特性を持っており, さらに患者の語りの文脈を重 視するために木下の提唱する修正版グラウンデッド ・ セオリー・アプローチ (Modified Grounded Theory Approach）の手法(6), 亿) に基づき，分析した．分析焦点 者は「TEVARを受けた後期高齢者」とし，分析テー マは「TEVARを受けた後期高齢者の治療体験」とし た.

まず，得られた 1 人ずつのデー夕を，分析テーマ を意識した上で, 何度も読み直し, データの中から分 析テーマに関するバリエーション（具体例）を抽出 した．抽出したバリエーションを分析焦点者である TEVAR を受けた後期高齢者にとってどのような意味 を持つのか多角的に解釈し, 抽出したデー夕を限定的 に確定した上で, 分析の最小単位である概念名を決定 した，概念生成時には，解釈を多角的に試みながら， 類似性だけでなく対極例がないかデー夕を継続比較分 析し解釈が染意的に偏る危険性を防いだ. 次に複数の 概念の相互関係を検討しカテゴリーを生成し，さらに 各カテゴリーの相互関係から局面を生成した. デー夕 から新たな概念が生成されなくなった時を理論的飽和 とし, 分析を終了した. 全分析過程において, 質的研 究の専門家のスーパーバイズを受け分析内容の信頼性 の確保に努めた.

\section{4. 倫理的配慮}

本研究は研究者の所属する研究倫理審查委員会の承 認 (承認番号第 1753 番) 及び研究実施施設の医学部 研究倫理審査委員会の承認（承認番号 2014-045）を 得て実施した。

対象者の選定に扔いて外来担当医師が診察後に身体 的・精神的に研究協力が可能と判断した場合にまず, 対象者に研究者を紹介して頂いた，その後，研究者は 対象者に自己紹介を行った後, 研究協力の可否を確認 した. 研究に興味を示した場合, 書面を用いて研究目 的, 研究方法, 個人情報の保護, デー夕の保管方法, 研究終了後にデー夕を一定期間保管しその後破裹する こと, 研究結果は個人が特定されないように公表する 
ことなどを説明した.ささらに，研究の参加，不参加， 途中辞退の場合も, 治療・診察に不利益が生じないこ とを説明した，説明後，同意が得られれば，研究同意 書に署名を依頼した，研究同意書への署名をもって研 究参加に承諾したとみなした。 同意撤回に関しては, いつでも撤回可能であること, 郵送やメールでの返信 でよいことを説明した，面接時においては対象者の体 調や疲労に十分注意し, 出来る限り負担がかからない よう配慮し, 対象者の疲労等がみられる場合には面接 時間を短縮あるいは中止した。

\section{IV. 結果}

\section{1. 対象者概要}

調查期間中に外来受診をした患者で，条件を満た す対象候補者 18 名に依頼し, 男性 7 名, 女性 6 名の 13 名から同意が得られた. 平均年齢 $78.3( \pm 3.9)$ 歳, 入院期間 12.69 （土6.5）日であった. 研究の同意が得 られなかった 5 名の理由は外来受診による疲労や帰宅 を急いでいるため時間が取れないなどであった，対象 者の概要は表 1 に示す.

\section{2. 面接の概要}

面接調査は，対象者の外来受診時に，1 人につき 1 回実施した。総面接時間は 405 分, 1 回あたりの平均 は約 31 分, 66,425 文字の逐語録となった.

\section{3. 分析結果}

患者の語りについて, 33 の概念, 11 のカテゴリー が抽出された。ささらに，カテゴリーは「治療への期待 と結果」,「治療と老いの双方の影響で生じた日常生活 上の困難」,「治療と老いに対して抱いた前向きな価值 観」の 3 局面に分類された（表 2 ）. 各局面について, カテゴリーを【】, 概念を〈〉, インタビューデー 夕からの抜粋を『』, 斜字を用いて説明する. 引用 部分の後に対象者の No. を［］元す．尚，概念は 文脈に沿って語尾を一部変化させた.

\section{1 ) 治療への期待と結果}

（1）大動脈瘤の診断は青天の霹靂

対象者は，TAA が診断された時，『言われるとびっ くりするような話になるんだけれど，言われるまで全 く何にもない状態なんだよね。（中略〜）ある日突 然わかる、ほいで, うろたえる。 [12]』など, 【大動 脈瘤の診断は青天の霹靂】と驚きを隠せていなかっ た.

\section{（2）手術か天寿全うか葛藤し決断}

手術を決断する際には，『車を運転していて，瘤が 破裂したら秒速で死言われたけど，自分と妻が一 緒に事故で二人だけで死ねるならいいけど，他人様に 迷惑をかけるかもしれない，かけてはいけないと思っ た. だから手術を思い切って受けようと思った［8］』 などと, 〈合併症のリスクはあるが破裂して死ぬより は手術を選択する〉と考えていた。また，〈心蔵に近

\section{表 1 対象者の概要}

\begin{tabular}{|c|c|c|c|c|c|c|c|}
\hline No. & 年齢 & 性別 & 大動脈瘤の部位 & 術式 & $\begin{array}{c}\text { 入院期間 } \\
(\text { 日) }\end{array}$ & $\begin{array}{l}\text { 手術から面接日 } \\
\text { までの期間（日） }\end{array}$ & 大動脈瘤治療歴 \\
\hline 1 & 75 & M & 弓部 & 2 期的 hybrid ${ }^{* 1}$ & 8 & 95 & \\
\hline 2 & 75 & $\mathrm{~F}$ & 弓部 & 1-debranch ${ }^{* 2}$ TEVAR & 11 & 322 & \\
\hline 3 & 76 & M & 弓部 & 2-debranch TEVAR & 10 & 84 & \\
\hline 4 & 76 & $\mathrm{~F}$ & 下行 & TEVAR & 26 & 231 & 大動脈解離 $\mathrm{B}$ 型 保存療法 \\
\hline 5 & 76 & M & 下行 & TEVAR & 11 & 372 & ThAAA ${ }^{* 3}$ 人工血管置換術 \\
\hline 6 & 76 & $\mathrm{~F}$ & 下行 & TEVAR & 9 & 406 & 大動脈解離 B 型 保存療法 \\
\hline 7 & 76 & $\mathrm{~F}$ & 下行 & TEVAR & 7 & 648 & \\
\hline 8 & 79 & M & 弓部 & 2 期的 hybrid & 10 & 567 & \\
\hline 9 & 79 & M & 弓部 & 2-debranch TEVAR & 14 & 147 & $\mathrm{AAA}^{* 4}$ 人工血管置換術 \\
\hline 10 & 79 & $\mathrm{~F}$ & 下行 & TEVAR & 10 & 424 & \\
\hline 11 & 81 & M & 下行 & TEVAR & 10 & 183 & AAA人工血管置換術 \\
\hline 12 & 82 & M & 下行 & TEVAR & 11 & 207 & \\
\hline 13 & 89 & $\mathrm{~F}$ & 下行 & TEVAR & 28 & 349 & 大動脈解離 B 型 保存療法 \\
\hline
\end{tabular}

*1 2 期的hybrid：1 回目に弓部置換術を行い 2 回目にステントグラフト内挿術を施行する

*2 debranch : 頸部分岐動脈にバイパス術を併用する. 数字はバイパス数を表す

${ }^{*} 3$ ThAAA：胸腹部大動脈瘤 ${ }^{*} 4$ AAA：腹部大動脈瘤 
表 2 TEVARを受けた後期高齢者の治療体験

\begin{tabular}{|c|c|c|}
\hline 局面 & カテゴリー & 概念名 \\
\hline \multirow{4}{*}{$\begin{array}{l}\text { 治療への } \\
\text { 期待と結果 }\end{array}$} & 大動脈瘤の診断は青天の霹靂 & 大動脈瘤の診断は青天の霹靂 \\
\hline & 手術か·天寿全うか葛藤し決断 & $\begin{array}{l}\text { 合併症のリスクはあるが破裂して死ぬよりは手術を選択する } \\
\text { 手術せず寿命を全うする選択もある } \\
\text { 心臟に近い手術であるため死まで覚悟して臨む } \\
\text { 治療に関する情報収集を自分なりに行う } \\
\text { 大きく切らず短時間の手術方法は手術決断の後押しとなる } \\
\text { 大動脈瘤の経過を診てもらっている安心感から手術の覚悟を決めやすい } \\
\text { 医師に絶大な信頼をおき最善の治療選択を委ねる }\end{array}$ \\
\hline & 想像より体の負担の軽い手術 & $\begin{array}{l}\text { 合併症が起きずに終わったことは奇跡的と思う } \\
\text { 大きく切った手術経験があるからこそ切らない治療による体の負担の軽さを実感する } \\
\text { ステントグラフト治療を受けることが出来る時代になりその恩恵は素晴らしい } \\
\text { 実際に想像していたより楽に終わったと感じる }\end{array}$ \\
\hline & 決して楽ではない手術 & $\begin{array}{l}\text { 全身麻酔であり体力的にきついと感じ決して楽ではない } \\
\text { 背中に入れた管が痛くて自由に動けずきつい } \\
\text { 楽観的に軽く手術を捉えていたからこそつらさを実感する }\end{array}$ \\
\hline \multirow{3}{*}{$\begin{array}{l}\text { 治療と老いの } \\
\text { 双方の影響で } \\
\text { 生じた日常 } \\
\text { 生活上の困難 }\end{array}$} & 身体的な機能低下の実感 & $\begin{array}{l}\text { 短期間で急激な足の筋力低下を著明に感じる } \\
\text { すぐには入院前と同じ生活レベルには戻らない } \\
\text { 回復したと思うまで時間がかかる }\end{array}$ \\
\hline & $\begin{array}{l}\text { 後遺症と老いによる不調で } \\
\text { 思い通りに送れない生活 }\end{array}$ & $\begin{array}{l}\text { 手の痺れや嗄声, 浮腫にもどかしさを覚える } \\
\text { 今まで出来ていたことが思ったように出来ない } \\
\text { 老いによる不調が現れる }\end{array}$ \\
\hline & $\begin{array}{l}\text { 欲しい情報や援助が得られないと } \\
\text { 感じるもどかしさ }\end{array}$ & $\begin{array}{l}\text { ステントグラフトがずれないか心配になる } \\
\text { 瘤とステントグラフトの位置関係について疑問を持つが医療者に聞けない } \\
\text { 後遺症への対処や日常生活上の注意点などの具体的な説明や援助が欲しいが得られない }\end{array}$ \\
\hline \multirow{4}{*}{$\begin{array}{c}\text { 治療と老いに } \\
\text { 対して抱いた } \\
\text { 前向きな価値感 }\end{array}$} & 自立した日常生活が維持出来る価値 & \begin{tabular}{|l} 
自分で体を動かせる今の状態を維持していきたいと思う \\
完全に元に戻らなくても破裂して死ぬよりは自立した日常生活を送れることに価値がある
\end{tabular} \\
\hline & 命と引き換えに目をつむる後遺症 & 命と引き換えに後遺症には目をつむる \\
\hline & $\begin{array}{l}\text { 回復に向け努力しながら } \\
\text { 余生の生き方を再構築 }\end{array}$ & \begin{tabular}{|l} 
破裂の不安から解放される \\
余生の目標や希望を抱く \\
入院前の体力を取り戻すために日常生活に少しずつ運動を取り入れる \\
落ちた食欲を戻すために食事の工夫をする
\end{tabular} \\
\hline & 病気を契機に考える最期の迎え方 & $\begin{array}{l}\text { 社会に支えてもらいながら生きることに後ろめたさを感じる } \\
\text { 病気になったことで自分のエンディングについて考えるようになる }\end{array}$ \\
\hline
\end{tabular}

い手術であるため死まで覚悟して臨む〉という者もい た.

一方で，『外来で先生に手術をした方がいいと言わ れたけれども，手術をすることに対して劣んだ。手術 のために入院したあとまで，ずっと少んだ、〜略〜 後期高齢者だし，80歳前だったから，手術しないで そのままでも良いかと思った。ここまで生きて来れた のもわがままだと思っている. [8]』と〈手術せず寿 命を全うする選択もある〉と思う者もいた。

また，手術の決断までに，〈治療に関する情報収集 を自分なりに行った〉り，『ステントグラフト療法が
なかった時代の仲間はね，手術を諦めたりする。それ を見てますから． [12]』と〈大きく切らず短時間の手 術方法は手術決断の後押しとなって〉いた. さらに, 過去に大動脈瘤の治療経験がある対象者は〈大動脈瘤 の経過を診てもらっている安心感から手術の覚悟を決 めやすい〉状況であった。

『まあ,こうなったら信頼関係しかないね.ややって 失敗したこんな病院に行くんじゃなかったなと感じ ても後の祭りだもんね，本当に決めたら，その先生を 信頼してやるしかない， [5]』と〈医師に絶大な信頼 をおき最善の治療選択を委ねる〉と語った。 
このように, 対象者は手術を決断する際に, 【手術 か天寿全うか葛藤し決断】していた.

(3) 想像より体の負担が軽い手術

TEVAR の施行後,『その前の手術の時はお腹から 切って肩甲骨の下まで切っています，骨一本ない及た いそその時にきつかったから簡単な方法はないですか という話をしていたら，ステントグラフトでやりま しょうということにしてくれたこれは楽だなと思い ました：[5]』など〈大きく切った手術経験があるか らこそ切らない手術による体の負担の軽さを害感し〉 ていた.

さらに、『本当にね，手術前の先生のお話しだと， 何が起きても, それこそ, 脳梗塞であったり麻瘏で あったり，でも，それがない状況，全部クリアでき た．奇跡的． [13]』などと〈合併症が起きずに終わっ たことは奇跡的と思って〉いた。

〈ステントグラフト治療を受けることが出来る時代 になりその恩恵は素晴らしく〉,『手術が終わって気が 付いた時に痛みも何もなかったから，こんなもんか と. 全然痛みもないし，つらいということもなかった ですね。こんな簡単に終わっちゃうのかと.もっと, 手術が終わったあとも, 入院中も痛いとか苦しいのか と思ったんだけど，そういうのが全然ないから。こん なに，意外と楽に終わっちゃうんだな［3]』などと 〈実際に想像していたより楽に終わった〉と語った.

このように, 手術後【想像より体の負担が軽い手 術】と感じた対象者がいた。

（4）決して楽ではない手術

『脊檤に保護するための管を入れた時，あれは痛 かった，一番つらかった，きつかった［10]』などと 脊骾ドレナージを施行するため, 〈背中に入れた管が 痛くて自由に動けずきつい〉状態であった，また，局 所的な麻酔ではなく,『ステントって簡単なように言 われているじゃないですか，体に負担が少ないとか， でも，体力的にきつい部分も感じましたし，全身麻醉 もしますし，精神的な不安はありました，治療を軽く 見ていたのかもしれません，[4]』などと〈全身麻酔 であり体力的にきついと感じ決して楽ではない〉と 語った，さらに，〈楽観的に軽く手術を捉えていたか らこそつらさを実感する〉姿もみられた。

このように, 手術後【決して楽ではない手術】と感 じた対象者もいた。

\section{2 ) 治療と老いの双方の影響で生じた日常生活上 の困難}

（1）身体的機能の低下の実感

退院後、『入ったのは 1 週間ぐらいだったかな.す ぐ退院して，そうしたらね，歩けないんだよ，今まで こんな経験ない．[11]』などと〈短期間で急激な足の 筋力低下を著明に感じて〉いた。

また、『ただ，疲れますよね。あの，10分ぐらい動 くともう10分以上休㮩しないと. それが，1 か月半 ぐらい続きました、やっぱり，ちょっと動くと疲れま すよね．［2]』などと〈すぐには入院前と同じ生活レ ベルには戻らない〉と感じていた.

さらに、『半年たってやっと，声が普通のように喋 れるようになったし，むくみもなくなった，普通に生 活して，半年かかった［1]』と〈回復したと思うま で時間がかかって〉いた。

このように, 退院後の生活において, 対象者は【身 体的機能の低下の実感】をしていた。

（2）後遺症と老いによる不調で思い通りに送れな い生活

『歩くには何ら支障はないんだけれども，手だけ。 これ以上指が伸びなくてね，曲がった状態になったま ま触るとしびれている，手の指の回りも手の内もしび れている. [9]』と手術の後遺症である〈手の痺れや 嗄声, 浮腫にもどかしさを覚えて〉いた.

『長距離が歩けないもんですから，バスに乗って買 い物が出来ないんです，買い物が全然できない，手術 する前はね，月に2 回俳句をやりに行っていたので すがね，電車に乗れなくなっちゃった［13]』などと 〈今まで出来ていた事が思ったように出来なく〉なっ ていた.

『私の場合は難聴がまた，悪くなってきたので，す ごく神経が疲れる，だから，呼ばれるのも聞こえな かったり，すごく緊張しちゃうんです、やっぱり下降 気味っていうのをしみじみ感じます。[10]』と〈老い による不調が現れて〉いた。

このように，対象者は【後遺症と老いによる不調で 思い通りに送れない生活】を送っていた。

（3）欲しい情報や援助が得られないと感じるもど かしさ

日常生活を送る中で，『力を入れたりすると，ステ ントの位置がずれちゃうんじゃないかと思うから，な んとなく, 力の入れ方が穏やかになって, 姿勢が悪く 
なるんだよね，姿勢をよくするということは結構，あ る程度力を入れないといけないからね，[12]』と〈ス テントグラフトがずれないか心配し〉ていた.

『ステントの中に瘤があると思いこんでるから，な んだか，つじつまが合わないと思って，先生にお聞き してもなんだか，納得がいかない，しつこく聞くわけ にはいかないし［2]』などと〈瘤とステントグラフ トの位置関係について疑問を持つが医療者に聞けな い〉という思いを抱いていた.

さらに、『そんなことしたらダメだよとかステント が馿染むようにこう受け身でやるといいっていう動 作はわからないんだよな、そういう説明ないもんね。 [12]』と〈後遺症への対処や日常生活上の注意点など の具体的な説明や援助が欲しいが得られない〉と感じ ていた。

このように，対象者は【欲しい情報や援助が得られ ないと感じるもどかしさ】を抱えていた.

3 ) 治療と老いに対して抱いた前向きな価值観

(1) 自立した日常生活が維持出来る価値

対象者は『今のままでいられれば，今のままが一番 ですよね．普段と変わらない動きをしている，[3]』 と〈自分で体を動かせる今の状態を維持していきたい と思って〉いた.

『でもまあ，動脈瘤を抱えて，いつって思っている よりは，多少しびれても歩けるし，血痰は出てますけ れど，日常生活は送れる，それを天秤にかけた時に やっぱり，ステントの手術はありがたいですよね，何 しろ，こんなに長く生きるとは思わなかった，だから， 生かしてもらってありがたいどっちって言われたら， 破裂した時の方が迷惑かけるなと思うので，元通り にならなくてもね。まあまあしょうがない［13]』と 〈完全に元に戻らなくても破裂して死妙的は自立し た日常生活を送れることに価值がある〉と感じていた．

このように, 対象者は【自立した日常生活が維持出 来る価値】を見出していた。

（2）命と引き換えに目をつむる後遺症

『後遺症は何の病気にも㧫は，多少ですよね，多 少の少のほうだとは思うんですけれども，多少はある とは今，感じてはいるんです、けれども，それはしか たがないかなと思って。これだけ，元気でいられるか らそれぐらいはしかたがないかな：7]』などと【命 と引き換えに目をつむる後遺症】を抱えながら, 命が 助かったと命の大事さを思い生活をしていた。
（3）回復に向け努力しながら余生の生き方を再構築 さらに, 〈破裂の不安から解放され〉, 『大動脈瘤も ステントをすれば，もう少し生きられるなっていうこ とで，すごく希望をもって，少しでも元気にしてくだ さったので，社会に還元したいなと思っています，ボ ランティアをやっております。［7]』など〈余生の目 標や希望を抱いて〉いた。

そして，『息子にウォーキングを勧められて，毎朝， 早く起きて 30 分ぐらいウォーキングをやっています. [10]』と〈入院前の体力を取り戻すために日常生活に 少しずつ運動を取り入れ〉,〈落ちた食欲を戻すために 食事の工夫をし〉ていた。

このように, 対象者は【回復に向け努力しながら余 生の生き方を再構築】していた。

\section{（4）病気を契機に考える最期の迎え方}

時間の経過と共に, TAA を治すためにかかった医 療費を振り返り，『若い人たちに支えてもらっている わけでしょ，長生きすることが本当にいいことか分か らないよね，若いときには病気をしたことがなくて， 保険料なんて払う必要はないって文句を言っていたり したけれど，今は，社会に迷惑をかけちゃっていると 思うね，本当に生きていることが申しわけないと思 う. [8]』と〈社会に支えてもらいながら生きること に後ろめたさを感じて〉いた，一方で, 手術がターニ ングポイントとなり，〈病気になったことで自分のエ ンディングについて考えるようになっていた〉.

このように，対象者は【病気を契機に考える最期の 迎え方】を見つけようとする姿があった。

\section{TEVAR を受けた後期高齢者の治療体験の結果図}

患者の語りから抽出されたカテゴリー, 局面をもと に, TEVARを受けた後期高齢者の体験を図式化した。 時間の経過を横軸に, 局面の相互関倸を, 時間経過を 踏まえ配置した．また，局面に属するカテゴリーは概 念が得られた時期にあわせ, カテゴリーをおき, 対象 者の思いや感じた困難の大きさに変化がみられたもの は拡大や縮小する形で表現した．対象者が診断から手 術を経て退院までの期間に, 低侵襲治療に期待を持つ 一方で, 手術をしないで天寿を全うしたいと思い葛藤 を抱いていた．治療後は体の負担の軽い手術と感じる 者と楽ではないと感じる者がおり,「治療への期待と 結果」の中に相反する思いがみられる. 対象者は退院 後に,「治療と老いの双方の影響で生じた日常生活上 


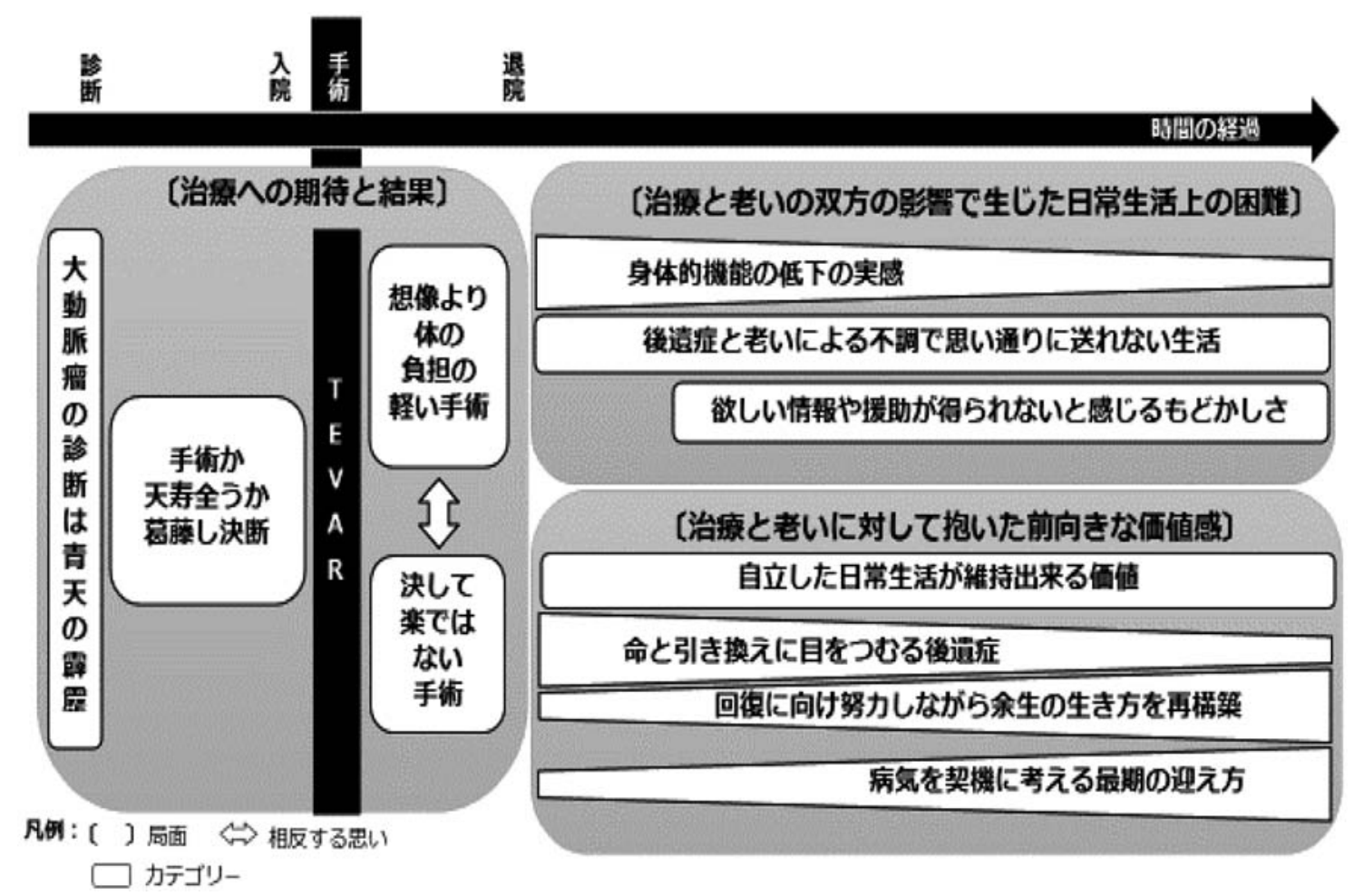

図 TEVAR を受けた後期高齢者の治療体験

の困難」と「治療と老いに対して抱いた前向きな価值 観」を同時に抱えていた. そのため, この 2 局面は並 べて配置した。

\section{V. 考察}

\section{1. 後期高齢者の治療後の日常生活の特徵}

TEVAR を受けた後期高齢者の治療後の日常生活の 特徴は，治療によって生じた身体的な機能の低下や後 遺症による不調を感じるだけでなく,「老い」に伴っ て生じる機能障害を抱えながら日常生活を送ってい た，そして，高齢者だからこそ，【自立した日常生活 が維持出来る】ことに価值を見出していた.

TEVAR は早期離床，入院期間が短いことや体への 負担が少ないため回復が早いというメリットが強調 されている。結果では，入院期間は 12 日間であった が, 退院後, 対象者は【身体的な機能の低下の実感】 をし，【後遺症による不調で思い通りに送れない生活】 を行っていた。この結果は，TAA に対し人工血管置 換術を受けた患者が術後の合併症や様々な苦痛症状, 体力の低下などを自覚する ${ }^{4)}$ と同様の結果であった.
しかしながら，TEVARの適用は後期高齢者が大半を 占めているため,「老い」に伴って生じる機能障害も 抱えていた，対象者は，体重減少や食欲低下，聴力の 衰え等を含めた生理的機能の低下を訴えていた。高齢 者は若年者と異なり予備機能の低下を背景に, 様々な 機能障害を起こしやすいという特徵がある。だからこ そ，治療による影響だけではなく，「老い」に伴う不 調を抱えながら日常生活を送っていることを理解する 必要がある。 また，様々な不調を抱えながら日常生活 を送っていく中で，対象者は【自立した日常生活が維 持出来る】ことに価值を見出していた．自立した日常 生活を送ることが出来ている今の状態が大事なのであ る。家族に迷惑をかけることなく日常生活を送りた いのである.さらに, 対象者は, 【回復に向け努力し, 余生の生き方を再構築】する姿がみられた，後遺症や 老いによる低下は否定的なことと言える。しかし，回 復に向け努力をしながら余生の生き方を再構築する前 向きな姿がみられた。これはTEVARを受けた対象者 が, 先行研究と同様に, 身体機能の低下やそれに伴う 老いの自覚という一見否定的に思える体験を通して, 自分らしさを発達的に変容させ未来に向かって生きて 
いく力を産み出せた ${ }^{8)}$ からだと考える.ささらに, 対象 者は【病気を契機に考える最期の迎え方】を模索する 姿があり, 最期までどのように生きていきたいのかを 考えながら生きる姿があった。

\section{TEVAR を受ける高齢患者への看護支援の検討}

高齢患者が手術を受けるが故, 治療選択の際に手術 を受けないという選択肢を考えても良いと考える.さ らに，治療後は手術の影響だけではなく「老い」に伴 う変化に着目することが重要である。高齢患者が術 後, 自分の余生を肯定し, 自立した日常生活が維持出 来るように看護援助を行うことが必要不可欠である。

TEVAR は体に負担が少なく，【想像より体の負担 の軽い手術】であったと感じていた者がいた．しか し, TEVARはどの患者に対しても必ずしも体に負担 が少ない治療と言い切れない，なぜなら，対象者の中 には後遺症が生じている者や,【決して楽ではない手 術】と感じた者がいるからである. TEVARも他の手 術と同様に手術に伴う利益と不利益は存在し，必ずし も体に負担が少ないとは言い切れない，最終的に手術 の決断をしていたが，決断までには【手術か・天寿全 うか葛藤】がみられた，対象者は，TAA の破裂は怖 いと感じながらも，手術をせず破裂なく，数年間生き て天寿を全う出来るかもしれないと考えていた。つま り, 手術は必要かもしれないが, 手術をしない選択肢 もあるのではないかと迷い葛藤していた。臟手術を 受けた患者は，最終的に手術を受けることを自分らし く生きるための手段として意味づけた ${ }^{9)}$ と先行研究で も見られるように，手術の決断を自分らしく生きるた めに選択することは重要である。ささらに, 治療方針を 決定するためには，患者が主体的に意思決定を行うこ とが不可欠であり，主体的な意思決定は闘病の姿勢に も大いに反映される (1) $^{10}$ た, 主体的に高齢患者が意 思決定を出来る環境が必要である。 また, 超高齢者が 治療を受ける際に，個別性に富んだ老いのありように

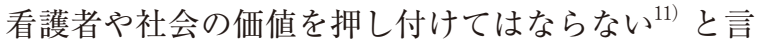
われているように，医療者の価值観を押し付けてはい けない，だからこそ，時に，低侵襲治療と言われる TEVAR であっても手術を受けることを望まないとい う意思を高齢患者は医師に示すかもしれない，その際 に，医療者からの徹底した情報提供がなされ，看護師 は高齢患者の擁護者となり, 患者が熟考出来る環境作 りを行うことが必要である．高齢患者自身の人生にお
いて，手術を受ける・受けないのどちらの選択をした としても自分の余生を肯定出来るように看護援助を行 うことが重要である.

対象者は, 退院後の生活において, 【後遺症と老い による不調で思い通りに送れない】という現状があっ た、ステントグラフトそのものよる不安, 後遺症や老 いに伴う機能低下による日常生活上の困難などを抱え ている. しかしながら, 対象者は具体的な説明や援助 を求めているにも関わらず，得られないともどかしさ を抱えていた．ステントグラフトが動くとずれてしま うのではないか，手のしびれはどのような対処をすれ ば和らぐのかなどに対して具体的にわかりやすい説明 や指導を求めている．看護師は個人の差が大きい高齢 患者に対して, 正しい知識を伝え, 具体的な看護援助 が求められている.

\section{VI. 結語}

胸部大動脈瓷ステントグラフト内㨂術を受けた後 期高齢者は，【大動脈瘤の診断は青天の霹靂】と驚き， 【手術か・天寿全うか暮藤し決断】をしていた，手術 後,【想像より体の負担の軽い手術】と感じた者と 【決して楽ではない手術】と感じた者が扔り，「治療へ の期待と結果」の中に相反する思いが明らかとなっ た．退院後は【身体的な機能低下の実感】をし，【後 遺症と老いによる不調で思い通りに送れない生活】を 送りながら，【ほしい情報や援助が得られないと感じ るもどかしさ】を抱え，「治療と老いの双方の影響で 生じた日常生活上の困難」がみられた，一方で，【自 立した日常生活が維持できる価值】を見出し，命と引 き換えに後遺症には目をつむり，【回復に向け努力し ながら余生の生き方を再構築】し，病気を契機に最期 の迎え方を考え，「治療と老いに対して抱いた前向き な価值観」を見出していた．高齢患者が手術を受ける が故，治療の影響だけではなく老いに伴う変化に着目 することが重要である，そして，高齢患者が術後も自 立した日常生活が維持出来るような看護援助が重要で ある。

\section{VII. 研究の限界と今後の課題}

本研究は手術後に外来通院が可能である限られた対 象者，1施設から得られたデー夕のため，今後は，対 
象施設を増やし，更に詳細な検討を加える必要があ る.

\section{謝辞}

本研究を行うにあたり，研究に協力してくださった皆様に 深く感謝申し上げます。

なお，本論文は東京医科歯科大学大学院保健衛生学研究科 の修士論文を加筆修正したものである。

\section{文献}

1）日本循環器学会. 大動脈瘤・大動脈解離診療ガイドライ ン (2011 年改訂版). 2014.05.31.

http://www.j-circ.or.jp/guideline/pdf/JCS2011_takamoto_h.pdf

2）鈴木亨, 永井良三. Thoracic endovascular aortic repair (TEVAR) 1. 総論一般. 新しい診断と治療の $\mathrm{ABC} 42$ 循 環器 6 大動脈瘤 - 大動脈解離（改定第 2 版). 大阪：最 新医学社；2013. p.187-194.

3）森下清文，佐賀俊文，楢山耕平，他．八イブリッド弓 部大動脈瘤ステントグラフト留置術一Total debranching vs partial debranching の比較一. 日血外会誌. $2014 ; 23$ : 695-699.

4）三浦英恵, 井上智子, 志水秀行. 大動脈瘤手術患者の病
気認識と退院後の生活・療養行動に関する研究（第 2 部） 胸部大動脈瘤患者を対象にして. 日本循環器看護学会. $2008 ; 4(1): 35-44$.

5）上田稚代子．冠状動脈バイパス術を受ける患者の周術期 における体験の明確化. 和歌山県立医科大学保健看護学 部紀要. $2008 ; 4: 19-29$.

6）木下康仁. ライブ講義 M-GTA 実践的質的研究法修正版 グラウンデッド・セオリー・アプローチのすべて（第 1 版). 東京：弘文堂；2007. p.13-229.

7）木下康仁. グラウンデッド・セオリー・アプローチの実 践一質的研究の誘い一（第 1 版）。東京：弘文堂；2003. p.87-224.

8）岡崎素子。心臟手術を体験する高齢者の発達的変容の研 究. 日本看護科学学会誌 $1999 ； 19(2) ： 68-77$.

9）小林礼実，下平唯子。心臓手術を受けた患者の回復意欲 の構造. 日本クリティカルケア看護学会誌. $2014 ; 10(1)$ ： 41-50.

10）秋元典子，井上智子，岡田忍，他. 第 4 章意思決定と治 療選択．井上智子編集一監修．看護治療学の基本医療に よる身体侵襲を「視る」「診る」「看る」(第 1 版)，横浜： ライフサポート社；2013. p297-298.

11）田中美穂. 入院・治療中の超高齢者がもとめる看護体験 の記述と解釈. 日本看護研究学会雑誌; $2008 ; 31(2)$ : $37-46$. 